S F

255

A 6

1914

The Anneucan Ascaciation of hedical

milk Commivuons. hay ' 1912

Wethade and tandarde for the Production and Dustilution of centifeal hilp: 
$\%$ 
TREASURY DEPARTMENT

Public Health and Marine-Hospital Service of the United States

REPRINT FROM PUBLIC HEALTH REPORTS.-No. 85

\section{METHODS AND STANDARDS}

FOR THE PRODUCTION AND DISTRIBUTION OF "CERTIFIED MILK"

\section{Adopted by}

The American Association of Medical Milk Commissions

MAY 1, 1912

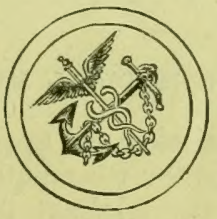

WASHINGTON

GOVERNMENT PRINTING OFFICE

1912 


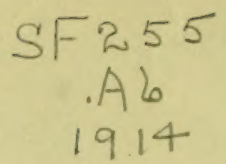

\section{METHODS AND STANDARDS FOR THE PRODUCTION AND DISTRIBUTION OF "CERTIFIED MILK." 12}

Adopted by the American Assoclation of Medical Mitk Commissions, Max $1,1912$.

Certified milk is the product of dairies operated in accordance with accepted rules and regulations formulated by authorized medical milk commissions to insure its purity and adaptability for infants and invalids.

The need for such a milk was experienced primarily by those engaged in the conservation of the life and health of infants. As a result there was formulated in 1892 a plan whereby certified milk would be produced by a dairyman under the control of a medical milk commission designated by a representative medical society.

The first rules designed for this purpose were those contained in an agreement entered into by a medical milk commission and the dairyman concerned. ${ }^{3}$

The rules contained in the original agreement mentioned represented the essential requirements for the production of certified milk. Following this precedent, other commissions were organized, which, in 1906, became federated into a national association known as the American Association of Medical Milk Commissions.

A fundamental object of this association was to bring about the uniformity of standards and their perfection. This result has been reached by the adoption from time to time of definite standards relating to the veterinary inspection of herds and farms, the medical inspection of employees handling the milk, and the bacteriological and chemical examinations as to quality and purity. The requirements with respect to these four topics have been previously reported upon by committees and adopted by the association, and at its last annual meeting provision was made for their further revision and amplification.

\section{ORGANIZATION OF MEDICAL MILK COMMISSIONS.}

The medical milk commission is appointed by a representative medical society, and acts under its auspices and for it, to encourage the production of milk of the highest possible standards of purity. No commission should be considered as certifying milk that does not conform to the standards adopted from time to time by the Association of Medical Milk Commissions. The commission should include

1 At the fifth annual meeting of the American Association of Medical Milk Commissions, held in Philadelphia May 25, 1911, a committee was appointed to revise the manual of working methods and standards for the guidance of medical milk commissions in the supervision of the production and distribution of certified milk. The committee consisted of Dr. J. W. Kerr (chairman), Dr. S., McC. Hamill, and Dr. Henry L. Coit. This their report was adopted at the sixth annual meeting, held at Louisville, K y., May 1, 1912, as the working methods and standards of the association. The association recommends them to com. ponent commissions as ideal and to be as closely approximated as possible. The report includes a statement coneerning the certified-milk movement, as well as the revised methods and standards, and is pubIished for the information of those interested in the improvement of public milk supplies.

2 Reprint from the Public Health Reports, Vol. XXVII, No. 24, June 14, 1912.

3 Bul. 56, Hygienic Laboratory, Public Health and Marine-Hospital Service, p. 615.

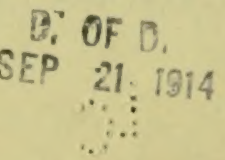


at least five members or a number sufficient to become responsible for and to carry on the following divisions of work: (a) The hygiene of the dairy, as it relates to the production and distribution of the milk; (b) the veterinary supervision of the herd; $(c)$ the medical supervision of the employees; $(d)$ the chemical and bacteriological examinations of the milk.

\section{DUTIES OF THE COMMISSION.}

After its organization the commission should designate a veterinarian, a physician, a chemist, and a bacteriologist to enforce its methods and standards which shall be the prevailing methods and standards of the American Association of Medical Milk Commissions, and these officers should be required to render regular reports of their inspections and examinations. A uniform written agreement should then be entered into with any dairyman who is desirous of undertaking the production of certified milk and the investigation of whose plant shows it to be properly equipped for such purpose. Such agreement shall require the observance of the methods and standards hereinafter mentioned.

Upon receipt of favorable reports from the several experts and committees which have made the investigations, the dairyman should be authorized, in accordance with the terms of the agreement, to employ the term "certified milk," and he shall be required to attach to all containers of any character used in distributing the milk produced under the agreement a certificate or seal bearing the term "certified milk," the name of the medical milk commission certifying it, and the day or date of production of the milk contained therein.

\section{HYGIENE OF THE DAIRY.}

UNDER THE SUPERVISION AND CONTROL OF THE VETERINARTAN.

1. Pastures or paddocks.-Pastures or paddocks to which the cows have access shall be free from marshes or stagnant pools, erossed by no stream which might become dangerously contaminated, at sufficient distances from offensive conditions to suffer no bad effects from them, and shall be free from plants which affect the milk deleteriously.

2. Surroundings of buildings.-The surroundings of all buildings shall be kept clean and free from accumulations of dirt, rubbish, decayed vegetable or animal matter or animal waste, and the stable yard shall be well drained.

3. Location of buildings.--Buildings in which certified milk is produced and handled shall be so located as to insure proper shelter and good drainage, and at sufficient distance from other buildings, dusty roads, cultivated and dusty fields, and all other possible sources of contamination; provided, in the case of unavoidable proximity to dusty roads or fields, the exposed side shall be screened with cheesecloth.

4. Construction of stables.-The stables shall be constructed so as to facilitate the prompt and easy removal of waste products. The floors and platforms shall be made of cement or other nonabsorbent material, and the gutters of cement only. The floors shall be properly graded and drained, and the manure gutters shall be from 6 to 8 inches 
deep and so placed in relation to the platform that all manure will drop into them.

5. The inside surface of the walls and all interior construction shall be smooth, with tight joints, and shall be capable of shedding water. The ceiling shall be of smooth material and dust-tight. All horizontal and slanting surfaces which might harbor dust shall be avoided.

6. Drinking and feed troughs.-Drinking troughs or basins shall be drained and cleaned each day, and feed troughs and mixing floors shall be kept in a clean and sanitary condition.

7. Stanchions.-Stanchions when used shall be constructed of iron pipes or hardwood, and throat latches shall be provided to prevent the eows from lying down between the time of cleaning and the time of milking.

8. Ventilation.- The cow stables shall be provided with adequate ventilation either by means of some approved artificial device, or by the substitution of cheesecloth for glass in the windows, each cow to be provided with a minimum of 600 cubic feet of air space.

9. Windows.-A sufficient number of windows shall be installed and so distributed as to provide satisfactory light and a maximum of sunshine; 2 feet square of window area to each 600 cubic feet of air space to represent the minimum. The coverings of such windows shall be kept free from dust and dirt.

10. Exclusion of fies, etc.-All necessary measures should be taken to prevent the entrance of flies and other insects, and rats and other vermin into all the buildings.

11. Exclusion of animals from the herd.--No horses, hogs, dogs, or other animals or fowls shall be allowed to come in contact with the certified herd, either in the stables or elsewhere.

12. Bedding.-No dusty or moldy hay or straw, bedding from horse stalls, or other unclean materials shall be used for bedding the cows. Only bedding which is clean, dry, and absorbent may be used, preferably shavings or straw.

13. Cleaning stable and disposal of manure.--Soiled bedding and manure shall be removed at least twice daily, and the floors shall be swept and kept free from refuse. Such cleaning shall be done at least one hour before the milking time. Manure, when removed, shall be drawn to the field or temporarily stored in containers so screened as to exclude flies. Manure shall not be even temporarily stored within 300 feet of the barn or dairy building.

14. Cleaning of cows.- Each cow in the herd shall be groomed daily, and no manure, mud, or filth shall be allowed to remain upon her during milking; for cleaning, a vacuum apparatus is recommended.

15. Clipping.--Long hairs shall be clipped from the udder and flanks of the cow, and from the tail above the brush. The hair on the tail shall be cut so that the brush may be well above the ground.

16. Cleaning of udders.- The udders and teats of the cow shall be cleaned before milking; they shall be washed with a cloth and water, and dry wiped with another clean sterilized cloth - a separate cloth for drying each cow.

17. Feeding. - All foodstuffs shall be kept in an apartment separate from and not directly communicating with the cow barn. They shall be brought into the barn only immediately before the feeding hour, which shall follow the milking. 
18. Only those foods shall be used which consist of fresh, palatable, or nutritious materials, such as will not injure the health of the cows or unfavorably affect the taste or character of the milk. Any dirty or moldy food or food in a state of decomposition or putrefaction shall not be given.

19. A well-balanced ration shall be used, and all changes of food shall be made slowly. The first few feedings of grass, alfalfa, ensilage, green corn, or other green feeds shall be given in small rations and increased gradually to full ration.

20. Exercise. - All dairy cows shall be turned out for exercise at least 2 hours in each 24 in suitable weather. Exercise yards shall be kept free from manure and other filth.

21. Washing of hands.-Conveniently located facilities shall be provided for the milkers to wash in before and during milking.

22. The hands of the milkers shall be thoroughly washed with soap, water, and brush and carefully dried on a clean towel immediately before milking. The hands of the milkers shall be rinsed with clean water and carefully dried before milking each cow. The practice of moistening the hands with milk is forbidden.

23. Milking clothes.-Clean overalls, jumper, and cap shall be worn during milking. They shall be washed or sterilized each day and used for no other purpose, and when not in use they shall be kept in a clean place, protected from dust and dirt.

24. Things to be avoided by milkers. - While engaged about the dairy or in handling the milk employees shall not use tobacco nor intoxi. cating liquors. They shall keep their fingers away from their nose and mouth, and no milker shall permit his hands, fingers, lips, or tongue to como in contact with milk intended for sale.

25. During milking the milkers shall be careful not to touch anything but the clean top of the milking stool, the milk pail, and the cow's teats.

26. Milkers are forbidden to spit upon the walls or floors of stables, or upon the walls or floors of milk houses, or into the water used for cooling the milk or washing the utensils.

27. Fore mitk.- The first streams from each teat shall be rejected, as this fore milk contains large numbers of bacteria. Such milk shall be collected into a separate vessel and not milked onto the floors or into the gutters. The milking shall be done rapidly and quietly, and the cows shall be treated kindly.

28. Milk and calving period.-Milk from all cows shall be excluded for a period of 45 days before and 7 days after parturition.

29. Bloody and stringy milk. - If milk from any cow is bloody and stringy or of unnatural appearance, the milk from that cow shall be rejected and the cow isolated from the herd until the cause of such abnormal appearance has been determined and removed, special attention being given in the meantime to the feeding or to possible injuries. If dirt gets into the pail, the milk shall be discarded and the pail washed before it is used.

30. Make-up of herd.-No cows except those receiving the same supervision and care as the certified herd shall be kept in the same barn or brought in contact with them.

31. Employees other than milkers.-The requirements for milkers, relative to garments and cleaning of hands, shall apply to all other persons handling the milk, and children unattended by adults shall not be allowed in the dairy nor in the stable during milking. 
32. Straining and strainers.-Promptly after the milk is drawn it shall be removed from the stable to a clean room and then emptied from the milk pail to the can, being strained through strainers made of a double layer of finely meshed cheesecloth or absorbent cotton thoroughly sterilized. Several strainers shall be provided for each milking in order that they may be frequently changed.

33. Dairy buitding.-A dairy building shall be provided which shall be located at a distance from the stable and dwelling prescribed by the local commission, and there shall be no hogpen, privy, or manure pile at a higher level or within 300 feet of it.

34. The dairy building shall be kept clean and shall not be used for purposes other than the handling and storing of milk and milk utensils. It shall be provided with light and ventilation, and the floors shall be graded and water-tight.

35. The dairy building shall be well lighted and screened and drained through well-trapped pipes. No animals shall be allowed therein. No part of the dairy building shall be used for dwelling or lodging purposes, and the bottling room shall be used for no other purpose than to provide a place for clean milk utensils and for handling the milk. During bottling this room shall be entered only by persons employed therein. The bottling room shall be kept scrupulously clean and free from odors.

36. Temperature of milk.-Proper cooling to reduce the temperature to $45^{\circ} \mathrm{F}$. shall be used, and aerators shall be so situated that they can be protected from flies, dust, and odors. The milk shall be cooled immediately after being milked, and maintained at a temperature between $35^{\circ}$ and $45^{\circ} \mathrm{F}$. until delivered to the consumer.

37. Seating of bottles.-Milk, after being cooled and bottled, shall be immediately sealed in a manner satisfactory to the commission, but such seal shall include a sterile hood which completely covers the lip of the bottle.

38. Cleaning and steritizing of bottles. - The dairy building shall be provided with approved apparatus for the cleansing and sterilizing of all bottles and utensils used in milk production. All bottles and utensils shall be thoroughly cleaned by hot water and sal soda, or equally pure agent, rinsed until the cleaning water is thoroughly removed, then exposed to live steam or boiling water at least 20 minutes, and then kept inverted until used, in a place free from dust and other contaminating materials.

39. Utensils. - All utensils shall be so constructed as to be easily cleaned. The milk pail should preferably have an elliptical opening 5 by 7 inches in diameter. The cover of this pail should be so convex as to make the entire interior of the pail visible and accessible for cleaning. The pail shall be made of heavy seamless tin, and with seams which are flushed and made smooth by solder. Wooden pails, galvanized-iron pails, or pails made of rough, porous materials, are forbidden. All utensils used in milking shall be kept in good repair.

40. Water supply.-The entire water supply shall be absolutely free from contamination, and shall be sufficient for all dairy purposes. It shall be protected against flood or surface drainage, and shall be conveniently situated in relation to the milk house.

41. Privies, etc., in relation to water supply.-Privies, pigpens, manure piles, and all other possible sources of contamination shall be so situated on the farm as to render impossible the contamination of the water supply, and shall be so protected by use of screens and 
other measures as to prevent their becoming breeding grounds for flies.

42. Toilet rooms.-Toilet facilities for the milkers shall be provided and located outside of the stable or milk house. These toilets shall be properly screened, shall be kept clean, and shall be accessible to wash basins, water, nail brush, soap and towels, and the milkers shall be required to wash and dry their hands immediately after leaving the toilet room.

TRANSPORTATION.

43. In transit the milk packages shall be kept free from dust and dirt. The wagon, trays, and crates shall be kept scrupulously clean. No bottles shall be collected from houses in which communicable diseases prevail, unless a separate wagon is used and under conditions prescribed by the department of health and the medical milk commission.

44. All certified milk shall reach the consumer within 30 hours after milking.

\section{VETERINARY SUPERVISION OF THE HERD.}

45. Tuberculin test.-The herd shall be free from tuberculosis, as shown by the proper application of the tuberculin test. The test shall be applied in accordance with the rules and regulations of the United States Government, and all reactors shall be removed immediately from the farm. ${ }^{1}$

46. No new animals shall be admitted to the herd without first having passed a satisfactory tuberculin test, made in accordance with the rules and regulations mentioned; the tuberculin to be obtained and applied only by the official veterinarian of the commission.

47. Immediately following the application of the tuberculin test to a herd for the purpose of eliminating tuberculous cattle, the cow stable and exercising yards shall be disinfected by the veterinary inspector in accordance with the rules and regulations of the United States Government. ${ }^{1}$

48. A second tuberculin test shall follow each primary test after an interval of six months, and shall be applied in accordance with the rules and regulations mentioned. Thereafter, tuberculin tests shall be reapplied annually, but it is recommended that the retests be applied semiannually.

49. Identification of cows. - Each dairy cow in each of the certified herds shall be labeled or tagged with a number or mark which will permanently identify her.

50. Herd-book record.-Each cow in the herd shall be registered in a herd book, which register shall be accurately kept so that her entrance and departure from the herd and her tuberculin testing: can be identified.

51. A copy of this herd-book record shall be kept in the hands of the veterinarian of the medical milk commission under which the dairy farm is operating, and the veterinarian shall be made responsible for the accuracy of this record.

1 See Circular of Instructions issued by the Bureau of Animal Industry for making tuberculin tests and for disinfection of premises. 
52. Dates of tuberculin tests. - The dates of the annual tuberculin tests shall be definitely arranged by the medical milk commission, and all of the results of such tests shall be recorded by the veterinarian and regularly reported to the secretary of the medical milk commission issuing the certificate.

53. The results of all tuberculin tests shall be kept on file by each medical milk commission, and a copy of all such tests shall be made available to the American Association of Medical Milk Commissions for statistical purposes.

54. The proper designated officers of the American Association of Medical Milk Commissions should receive copies of reports of all of the annual, semiannual, and other official tuberculin tests which are made and keep copies of the same on file and compile them annually for the use of the association.

55. Disposition of cows sick with diseases other than tuberculosis.Cows having rheumatism, leukorrhea, inflammation of the uterus, severe diarrhea, or disease of the udder, or cows that from any other cause may be a menance to the herd shall be removed from the herd, placed in a building separate from that which may be used for the isolation of cows with tuberculosis, unless such building has been properly disinfected since it was last used for this purpose. The milk from such cows shall not be used, nor shall the cows be restored to the herd until permission has been given by the veterinary inspector after a careful physical examination.

56. Notification of veterinary inspector.-In the event of the occurrence of any of the diseases just described between the visits of the veterinary inspector, or if at any time a number of cows become sick at one time in such a way as to suggest the outbreak of a contagious disease or poisoning, it shall be the duty of the dairyman to withdraw such sickened cattle from the herd, to destroy their milk, and to notify the veterinary inspector by telegraph or telephone immediately.

57. Emaciated cows.- Cows that are emaciated from chronic diseases or from any cause that in the opinion of the veterinary inspector may endanger the quality of the milk, shall be removed from the herd.

\section{BACTERIOLOGICAL STANDARDS.}

58. Bacterial counts.-Certified milk shall contain less than 10,000 bacteria per cubic centimeter when delivered. In case a count exceeding 10,000 bacteria per cubic centimeter is found, daily counts shall be made, and if normal counts are not restored within 10 days the certificate shall be suspended.

59. Bacterial counts shall be made at least once a week.

60. Collection of samples. - The samples to be examined shall be obtained from milk as offered for sale and shall be taken by a representative of the milk commission. The samples shall be received in the original packages, in properly iced containers, and they shall be so kept until examined, so as to limit as far as possible changes in their bacterial content.

61. For the purpose of ascertaining the temperature, a separate original package shall be used, and the temperature taken at the time of collecting the sample, using for the purpose a standardized thermometer graduated in the centigrade scale.

62. Interval between milking and plating.-The examinations shall be made as soon after collection of the samples as possible, and in no 
case shall the interval between milking and plating the samples bo longer than 40 hours.

63. Plating.-The packages shall be opened with aseptic precautions after the milk has been thoroughly mixed by vigorously reversing and shaking the container 25 times.

64. Two plates at least shall be made for each sample of milk, and there shall also be made a control of each lot of medium and apparatus used at each testing. The plates shall be grown at $37^{\circ} \mathrm{C}$. for 48 hours. 65. In making the plates there shall be used agar-agar media containing 1.5 per cent agar and giving a reaction of 1.0 to phenolphthalein.

The following is the method recommended by a committee of the American Public Health Association for the making of the media, modified, however, as to the agar content and reaction to conform to the requirements specified in section 65 :

1. Boil 15 grams of thread agar in 500 c. c. of water for half an hour and make up wreight to $500 \mathrm{~g}$. or digest for 10 minutes in the autuclave at $110^{\circ} \prime^{\prime}$. Let this cool to about $60^{\circ} \mathrm{C}$.

2. Infuse $500 \mathrm{~g}$. finely chopped lean beef for 24 hours with its own weight of distilled water in the refrigerator.

3. Make up any loss by evaporation.

4. Strain infusion through cotton flannel, using pressure.

5. Weigh filtered infusion.

6. Add Witte's peptone, 2 per cent.

7. Warm on water bath, stirring until peptone is dissolved and not allowing temperature to rise above $60^{\circ} \mathrm{C}$.

8. To the 500 grams of meat infusion (with peptone) add $500 \mathrm{~g}$. of the 2 per cent agar, keeping the temperature below $60^{\circ} \mathrm{C}$

9. Heat over boiling water (or steam) bath 30 minutes.

10. Restore weight lost by evaporation.

11. Titrate after boiling one minute to expel carbonic acid.

12. Adjust reaction to final point desired +1 by adding uormal sodinm hydrate.

13. Boil two minutes over free flame, constantly stirring.

14. Restore weight lost by evaporation.

15. Filter through absorbent cotton or coarse filter paper, jassing the filtrate through the filter repeatedly until clear.

16. Titrate and record the final reaction.

17. Tube (10 c. c. to a tube) and sterilize in autoclave one hour at 15 pounds pressure or in the streaming steam for 20 minutes on three successive days.

66. Samples of milk for plating shall be diluted in the rsoportion of 1 part of milk to 99 parts of sterile water; shake 25 times and plate 1 c. c. of the dilution.

The committee on bacterial milk analyses of the American Public Health Association in Part IV of its report presented details with respect to plating apparatus and technique in part as follows:

Plating apparatus.-For plating it is best to have a water bath in whirh to melt the media and a water-jacketed water bath for keeping it at the required temperature; a wire rack which should fit both the water baths for holding the media tubes; a thermometer for recorling the temperature of the water in the water-jacketed bath, sterile 1 c. c. pipettes, sterile Petri dishes, and sterile dilution water in measured quantities.

Dilutions.-Ordinary potable water, sterilized, may be used fur dilutions. Occasionally spore forms are found in such water which resist ordinary autoclave sterilization; in such cases distilled water may be used or the autoclave pressure increased. With dilution water in 8-ounce bottles calibrated for 99 cubic centimeters * * * all the necessary dilutions may be made.

Short, widle-mouthed "blakes" or wide-mouthed French square bottles are more easily handled and more economical of space than other forms oi bottles or flasks.

Eight-ounce bottles are the best, as the required amount of dilution water only about haif fills them, leaving room for shaking. Long-fiber nonabsorbent cotton should be used for plugs. It is well to use care in selecting cotton for this purpose to avoid short-fiber or dusty cotton, which give a cloud of lint-like particles on shaking. Bottles * * * should be filled a little over the $99 \mathrm{c}$. c. * * * to allow for loss during sterilization. 
Pipctes.-Straight sides 1 c. c. pipettes are more easily handled than those with bulbs; they may be made from ordinary three-sixteenths inch glass tubing and should be about 10 inches in length.

Plating technique.-The agar after melting should be kept in the water-jacketed water bath between $40^{\circ} \mathrm{C}$. and $45^{\circ} \mathrm{C}$. for at least 15 minutes before using to make sure that the agar itself has reached the temperature of the surrounding water. If used too warm, the heat may destroy some of the bacteria or retard their growth.

Shake the milk sample 25 times, then with a sterile pijette transfer $1 \mathrm{c}$. c. to thie first dilution water and rinse the pipette by drawing dilution water to the mark and expelling; this gives a dilution 1 to 100 .

*** Then with a sterile pipette transfer 1 c. c. to the Petri dish, using care to raise the cover only as far as necessary to insert the end of the pipette.

Take the tube of agar from the water bath, wipe the water from outside the tube with a piece of cluth, remove the plug, pass the mouth of the tube through a flame, and pour the agar into the plate, using the same care as before to avoid exposure of the plate contents to the air.

Carefully and thoroughly mix the agar and diluted milk in the Petri dish by a rotary motion, avoiding the formation of air bubbles or slopping the agar, and aiter allowing the agar to harden for at least 15 minutes at room temperature, place the dish bottom down in the incubator.

Plating should always be done in a place free from dust or currents of air.

In order that colonies may have sufficient food for proper development $10 \mathrm{c}$. c. of agar shall be used for each plate.

67. Determination of taste and odor of milk.-After the plates have been prepared and placed in the inculbator, the taste and odor of the milk shall be determined after warming the milk to $100^{\circ} \mathrm{F} .{ }^{1}$

68. Counts.-The total number of colonies on each plate should be counted, and the results expressed in multiples of the dilution factor. Colonies too small to be seen with the naked eye or with slight magnification shall not be considered in the count.

69. Records of bacteriologic tests. - The results of all bacterial tesis shall be kept on file by the secretary of each commission, copies of which should be made available annually for the use of the American Association of Medical Milk Commissions.

\section{CHEMICAL STANDARDS AND METHODS.}

The methods that rinust be followed in carrying out the chemical investigations essential to the protection of certified milk are so complicated that in order to keep the fees of the chemist at a reasonable figure, there must be climinated from the examination those proceclures which, whilst they might be helpful and interesting, are in no sense necessary.

For this reason the determination of the water, the total solids and the milk sugar is not required as a part of the routine examination.

70. The chemical analyses shall be made by a competent chemist designated by the medical milk commission.

71. Method of obtaining samples.-The samples to be examined hy the chemist shall have boen examined previously by the bacteriologist designated by the modical milk commission, as to temperature, odor, taste, and bàcterial content.

72. Fat stendards.-The fat standard for certified milk shall be 4 per cent, with a permissible range of variation of from 3.5 to 4.5 per cent.

1 Should it bo deomed desirable and necessary to conduct tests for sediment, the presence of special bacteria, or the number of lencocytes the methods adopted by the committeo of the American publie Health Association should be followed. 
73. The fat standard for certified cream shall bo not less than 18 per cent.

74. If it is desircl to sell higher fat-percentage milks or ereams as certified mills or creams, the range of variation for such milks shall be 0.5 per cent on either side of the advertised pereentage and the range of variations for such creams shall be 2 per cent on either side of the advertised percentage.

75. The fat content of certificd milles and creams shall be detormined at least once each month.

76. The methods recommended for this purpose are the Babeock $(a)$, the Leffmann-Beam $(b)$, and the Gerber $(c)$.

(a) Babcoct; test.-The Babrock test is based on the fart that strong sulphuric ar-id will dissolve the nomfatty solid constituents of milk, and thus enable the fat to sciarate on standing. It can be conducted by any of the Babcock outfits which are purchasable in the market.

"The test is made by placing in the special test bottle IS grams (17.6 c. c.) of milk. To this is added, from a pipette, burette, or measuring bottle, $17.5 \mathrm{c}$. c. commerial sulphuric acid of a specific gravity of 1.82 to 1.83. The contents of the bottle aro carefully and thoronghly mixed by a rotary motion. The mixture becomes brom and heat is generated. The test bottle is now placed in a properly balanced centrifige and whirled for 5 minutes at a speed of from 800 to 1,200 revolutions per minute. II t water is then added to fill the bottle to the lower part of the neck, after which it is again whirled for two minutes. Fow, enough hot water is added to float the columm of fat into the graduated pertion of the neck of the bottle, and the whirline is repeated for a minute. The amount of fat is read while the neck of the bottle is still hot. The reading is from the upper limits of the menisens. A pair of calipers is of assistance in measuring the column of fat." (Jensen's Milk Hygiene, Leonard Pearson's 1ranslation.)

(b) Leffmann-Bcam test-The distinctive feature is the use of fusel oil, the effect of which is to produce a greater difference in surface tension between the fat and the liquid in which it is suspended, and thus promote its readier separation. This effert has been found to be heightened by the presence of a small amount of hydrochloric acid.

The test bottles have a capacity of about 30 c. c. and are provided with a gradliuted neck, each division of which represents 9.1 per cent by weight of butter fat.

Fifteen centimeters of the milk are measured into the bottle, 3 c. c. ci a nixture of cqual parts of amyl alcohol and strong hydrochloric arid added and mixed. Then 9 c. c. of concentrated sulphuric acid is added in portions of about $1 \mathrm{c}$. c.; after each addition the liquids are mixed by giving the bottle a grratory motion. If the fluil has not lost all of its milky color by this treatment, a little more conrentrated arid mist be added. The neck of the bottle is now immediately filled at about the zero point wilh one part sulphuric acid and two parts water, well mixed just before using. Both the liquid in the bottle and the diluted acid must be hot. The bottle is then placed at once in the centrifugal machine; after rotation from one to two minittes; the fat will collect in the neck of the bottle and the percentage may be read off.

(c) Gerber's test.-This test is applied as follows: The test bottles are put into the stand with the mouths uppermost; then, with the pipette designed for the purpose, or with an automatic measurer, $10 \mathrm{c}$. c. of sulphuric acid are filled into the test bottle, care being taken not to allow any to come in contact with the neck. The few drops remaining in the tip of the pipette should not be blown out. Then $11 \mathrm{c}$. c. of milk are measured with the proper pipette and allowed to flow slowly onto the acic!, so that the two liquids mix as little as possible. Finally, the amyl alcohol is added. (It is important to use the reagents in the proper order, which is-sulphuric acid, mil;, amyl alcohol. If the sulphuric acid is followed by amyl alcohol and the milk last, then the result is sometimes incorrect.) A rubber stopper, which must not be damaged, is then fitted into the mouth of the test bottle, and the contents are well shaken, the thumb being kept on the stopper to prevent it coming out. As a consirlerable amount of heat is generated by the action of the sulphuric acid on the milk, the test bottle should be wrapped in a cloth.

The shaking of the sample must be done thoroughly and quickly, and the test bottle inverted several times, so that the liquid in the neck becomes thoroughly mixed. By pressing in the rubber stopper the lieight of the liquid can be breught to about tho zero point on the scale.

If only a few samples have to be analyzed and the room is warm, the test bottles can be put ints the centrifuge without an? preliminary heating, otherw ise the test 
bottles must be warmed for a few minutes (not longer) in the water bath at a temperature of $60^{\circ}$ to $65^{\circ} \mathrm{C}$. When the temperature rises higher than this, say above $70^{\circ} \mathrm{C}$, the rubber stopper is liable tis be blown out of the test bottle. After the test bottles have been heated thry are arraiged symmetrirally in the centrifuge and whirled fir 3 to 4 minutes at a speed of about 1,000 revolutions per minute. When the centrifuge has a heating arrangement attached to it, the preliminary warming is not, of course, necessary. When the test bottles are taken out of the centrifuge, they are arain placed in the water bath at a temperature of $60^{\circ}$ to $65^{\circ} \mathrm{C}$., and left there for several minutes before being rearl: where the centrifuge is heated, the tubes can be read off as taken from the centrifuge.

By carefully screwing in the rubber stopper, or even by pressing it, the lower limit of the fat column is brought onto one of the main divisions of the scale, and then, by holling the test bottle against the light the height of the column of fat can be accurately ascertained. The lorrest point of the meniseus is taken as the level when realing the upper surface of the fat in a sample of whole milk, and the middle of the meniscus for separated milk.

If the column of fat is not clear and sharply defined, the sample must be again whirled in the centrifuge.

Each division on the scale is equivalent to 0.1 per cent, so it is very easy to read to 0.05 per cent, or, with a lens, to 0.025 per cent. If the number which is read off is multiplied by 0.1 , then the percentage quantity of fat in the milk is obtained; o. $g$. , if the number on the scale was 36.5, then the percentage of fat is 3.65. (Milk and Dairy Products, Barthel; translated by Goodwin, p. 71.)

77. Before condemning samples of milk which hare fallen outside the limits allowed, the chemist shall have determined, by control ether extractions, that his apparatus and his technique are reliable.

73. Protein standard.-The protein standard for certified milk shall be 3.50 per cent with a permissible range of variation of from 3 to 4 per cent.

79. The protein standard for certified croam shall correspond to the protein standard for certified milk.

so. The protein content shall be determined only when any special consideration seems to the medical milk commission to make it desirable.

81. It shall be determined by the Kjeldahl method, using the Gunning or some other reliable modification, and employing the factor $6.25 \mathrm{in}$ reckoning the protein from the nitrogen.

Kjiddull method.-Five cubic centimeters of milk are measured carefully into a flat-bottom 800 c. c. Jena flask, 20 c. c. of concentrated sulphuric acid (C. P.; sp. gr.; 1.S.1) are added, and 0.7 gram of mercuric oxid (or its equivalent in metallic mercury); the mixture is then heated over direct flame until it is straw-colored or perfectly white; a few crystals of potassium permanganate are now added till the color of the liquid remains green. All the nitrogen in the milk has then been converted into the form of ammonium sulphate. After cooling, $200 \mathrm{c}$. c. of ammonia-free distilled water are arlded, $20 \mathrm{c}$. c. of a solution of potassium sulphide (containing 40 grams sulphide per liter), and a fraction of a gram of porrdered zinc. I quantity of semi-normal HCl solution more than sufficient to neutralize the ammonia obtained in the oxidation of the milk is now carefully measured out from a delicate burette (divided into $\frac{1}{20} \mathrm{c} . \mathrm{c}$.) into an Erlenmeyer flask and the flask connected with a distillation apparatus. At the other end the Jena flask containing the watery alution of the ammonium sulphate? is comnected, after alding $50 \mathrm{c}$. c. of a concentrated soda solution (1 pound "pure potash" dissolved in 500 c. c. of distilled water and allowed to settle); the contents of the Jena flask are now heated to boiling, and the distillation is continued for 40 minutes to an hour, until all ammonia has been distilled over.

The excess of acid in the Erlenmeyer receiving flask is then accurately titrated back hy means of a tenth-normal standard ammonia solution, using a cochineal solution as an indicator. From the amount of acid used the per cent of nitrogen is of tained; and from it the per cent of casein and albumen in the milk by multiplying by $(6.25$. The amount of nitrogen contained in the chemicals used is determined by blank experiments and dedueted from the nitrogen obtained as described. (Farrington and Woll, Testing Milk and Its Products, p. 221.) 
82. Coloring matter and preservatives.-All certified milks and creams shall be free from adulteration, and coloring matter and preservatives shall not be added thereto.

83. Tests for the detection of added coloring matter shall be applied whenever the color of the milk or cream is such as to arouse suspicion.

Test for coloring matter.-The presence of foreign coloring matter in milk is easily shown by shaking $10 \mathrm{c}$. c. of the milk with an equal quantity of ether; on stancling, a clear ether solution will rise to the surface; if artificial coloring matter has been added to the milk, the solution will be yellow colored, the intensity of the color indicating the quantity added; natural fresh milk will give a colorless ether solution.-(Testing Milk and its Products, Farrington and Woll, p. 244.)

84. Tests for the detection of formaldehyde, borax, and boracic acid shall be applied at least once each month. Occasionally application of tests for the detection of salicylic acid, benzoic acid, and the benzoates are also recommended.

Test for the detection of formuldehyde.-Five cubic centimeters of milk is measured into a white porcelain dish, and a similar quantity of water added; $10 \mathrm{c}$. c. of $\mathrm{HCl}$, containing a trace of $\mathrm{Fe}_{2} \mathrm{Cl}_{6}$ is added, and the mixture is heated very slowly. If formaldehyde is present, a violet color will be formed.-(Testing Milk and Its Products, Farrington and Woll, p. 249.)

Test for boracic acid (borax, borates, preservaline, etc.).-One hundred cubic centimeters of milk are made alkaline with a soda or potash solution, and then evaporated to dryness and incinerated. The ash is dissolved in water, to which a little hydrochloric acid has been added, and the solution filtered. A strip of turmeric paper moistened with the filtrate will be colored redish brown when dried at $100^{\circ}($. on a watch glass, if boracic acid is present.

If a little alcohol is poured over the ash to which concentrated sulphuric acid has been added, and fire is set to the alcohol, after a little while this will burn with a yellowish-green tint, especially noticeable if the ash is stirred with a glass rod and when the flame is about to go out.-(Testing Milk and Its Products, Farrington and Woll, p. 247.)

Test for salicylic acid (salicylates, etc.) - Twenty cubic centimeters of milk are acidulated with sulphuric acid and shaken with ether; the ether solution is evaporated, and the residue treated with alcohol and a little iron-cllorid solution; a deep violet color will be obtained in the presence of salicylic acid.-(Testing Milk and Its Products, Farrington and Woll, p. 248.)

Test for benicoic arid.-Two hundred and fifty to five hundred cubic centimeters of milk are made alkaline with a few drops of lime or baryta water, and then evaporated to about a quarter of the bulk. Powdered gypsum is stirred into the remaining liquid until a paste is formed, which is then dried on the water bath. The gypsum only serves to hasten the drying, and pordered pumice stone or sand can be used equally well. When the mass is dry, it is finely powdered and moistened with dilute sulphuric acid and shaken out three or four times with about twice the volume of 50 per cent alcohol, in which benzoic acid is easily soluble in the cold, the fat only being dissolved to a very slight extent or not at all. The acid alcoholic liquid from the various extractions, which contains milk sugar and inorganic salts in addition to the benzoic acid, is neutralized with baryta water and evaporated to a small bulk. Dilute sulphuric acid is again added, and the liquid shaken out with small quantities of ether. On evaporation of the ether, the benzoic acid is left behind in almost pure state, the only impurities being small quantities of fat or ash.

The benzoic acid which is obtained is dissolved in a small quantity of warm water, a drop of sodium acetate and neutral ferric chloride added, and the red precipitate of benzoate of iron indicates the presence of the acid.-(Milk and Dairy Products, Barthel, translated by Goodwin, p. 121.)

85. Detection of heated milk.-Certified milk or cream shall not be subjected to heat unless specially directed by the commission to meet emergencies.

86. Tests to determine whether such milks and creams have been subjected to heat shall be applied at least once each month.

Detection of heated milk-Storch's method.-Five cubic centimeters of milk are poured into a test tube; a drop of weak solution of hydrogen dioxide (about 0.2 per cent) 
which contains about 0.1 per cent sulphuric acid is addled, and two drops of a 2 per cent solution of paraphenylendiamin (solution should be renewed quite often), then the fluid is shaken. It the milk or the cream becomes, at once, indigo blue, or the whey violet or reddish brown, then this has not been heated or, at all events, it has not beell heated higher than $78^{\circ}\left({ }^{\prime} .\left(172.5^{\circ} \mathrm{F}\right.\right.$.); if the milk becomes a light blu ish gray immediately or in the course of half a minute, then it has been heated to $79^{\circ}$ to $80^{\circ}$ ' $^{\prime}$. $\left(174.2^{\circ}\right.$ to $176^{\circ} \mathrm{F}$.). If the color remains white, the milk has been heated at least to $80^{\circ} \mathrm{C} .\left(176^{\circ} \mathrm{F}\right.$.). In the examination of sour milk or sour buttermilk, lime water must be added, as the color reaction is not shown in acid solution.

Arnold's guarac method. - A little milk is poured into a test tube and a little tincture of guriac is added, drop by (Irop. If the milk has not been heated to $80^{\circ} \mathrm{C}$. (176 $6^{\circ} \mathrm{F}$.) a blue zone is formed between the two fluids; heated milk gives no reaction, but remains white. The guaiac tincture should not be used perfectly fresh, but should have stood a few days and its potency have been determined. Therenfter it can be used indefinitely. These tests for heated milk are only active in the case of milks which have been heated to $176^{\circ} \mathrm{F}$. or $80^{\circ} \mathrm{C}$.- (Jensen's Milk Hygiene, Pearson's translation, p. 192.)

Mirroscopic test for heated (pasteurizcd) milk-Frost and Ravenel.-About 15 c. c. of milk are centrifuged for five minutes, or long enough to throw down the lencocytes. The cream layer is then completely removed with absorbent cotton and the milk drawn off with a pipette, or a fine-pointed tube attached to a (hapman air pump. Only about $2 \mathrm{~mm}$. of milk are left above the sediment which is in the hottom of the sedimentation tube.

The stain, which is an aqueous solution of safranin 0 , soluble in water, is then added very slowly from an opsonizing pipette. The important thing is to mix stain and milk so slowly that clotting does not take place. The stain is added until a deep oparue rose color is obtained. After standing three minutes, by means of the opsoniring pipette, which has been washed out in hot water, the stained sediment is then transferred to slides. A small drop is placed at the end of each of several slides and spread by means of a glass spreader, as in Wright's method for opsonic index determinations.

In an unheated milk the polymorphonuclear leucocytes have their protoplasm slightly tinged or are unstained.

In lieated milk the polymorphonuclear leucocytes have their nuclei stained. In milk heated to $63^{\circ} \mathrm{C}$. or above, practically all of the leucocytes have their nuclei dcfinitely stained. When milk is heated at a lower temperature the nuclei are not all stained above $60^{\circ} \mathrm{C}$. The majority, however, are stained.

S7. Specific gravity.-The specific gravity of certified milk shall range from 1.029 to 1.034 .

SS. The specific gravity shall be determined at least each month.

The Quevenne lactorlensimeter is recommended for the determination of the specific gravity. It is made like an ordinary aerometer and divided into degrees which correspment to a specific gravity from 1.014 to 1.040 , or only from 1.022 to 1.038 , since, by the latter division, a greater space is gained between the different degrees without unduly lengthening the instrument. From such a lactodensimeter one can easily read off four decimal places.

The milk the specific gravity of which is to be determined is well shaken and poured into a high glass eylinder of suitable diameter: the aerometer is dropped in slowly, in order to prevent its bobbing up) and down. (The bulb should be free from adhering air bubbles.) The figures on the stem are the second and third decimals of the numhers of the specific mavity, so that 34 is to be read 1.034. For this examination, the (emperature of the milk must be $15^{\circ} \mathrm{C} .\left(60^{\circ} \mathrm{F}.\right)$; if it is not, the specific sravity of the milk at $15^{\circ}('$. must he calculated from the specilic gravity found and from the temperature, for in milk inspection and analysis this is the standard.

METHODS AND REGULATIONS FOR THE MEDICAL EXAMINATION OF EMPLOYEES, THEIR IIEALTII AND PERSONAL IYGIENE.

89. A medical officex, known as the attending dairy physician, shall be solected by the commission who should reside near the dairy produreing cortified milk. He shill be a physician in good standing and authorized by law to practice medicine; he shall be responsible to the commission and subject to its direction. In case more than one dairy is under the control of the commission and they are in different locali- 
ties, a separate physician should be designated for employment for the supervision of each dairy.

90. Before any person shall come on the premises to live and remain as an employee, such person, before being engaged in milking or the handling of milk, shall be subjected to a complete physical examination by the attending physician. No person shall be employed who has not been vaccinated recently or who upon examination is found to have a sore throat, or to be suffering from any form of tuberculosis, venereal disease, conjunctivitis, diarrhea, dysentery, or who has recently had typhoid fever or is proved to be a typhoid carrier, or who has any inflammatory disease of the respiratory tract, or any suppurative process or infectious skin eruption, or any disease of an infectious or contagious nature, or who has recently been associated with children sick with contagious disease.

91. In addition to ordinary habits of personal cleanliness all milkers shall have well-trimmed hair, wear close-fitting caps, and have cleanshaven faces.

92. When the milkers live upon the premises their dormitories shall be constructed and operated according to plans approved by the commission. A separate bed shall be provided for each milker and each bed shall be kept supplied with clean bedclothes. Proper bathing facilities shall be provided for all employees on the dairy premises, preferably a shower bath, and frequent bathing shall be enjoined.

93. In case the employees live on the dairy premises a suitable building shall be provided to be used for the isolation and quarantine of persons under suspicion of having a contagious disease.

The following plan of construction is recommended:

The quarantine building and hospital should be one story high and contain at least two rooms, each with a capacity of about 6,000 cubic feet and containing not more than three beds each, the rooms to be separated by a closed partition. The doors opening into the rooms should be on opposite sides of the building and provided with locks. The windows should be barred and the sash should be at least 5 feet from the ground and constructed for proper ventilation. The walls should be of a material which will allow proper disinfection. The floor should be of painted or washable wood, preferably of concrete, and so constructed that the floor may be flushed and properly disinfected. Proper heating, lighting, and ventilating facilities should be provided.

94. In the event of any illness of a suspicious nature the attending physician shall immediately quarantine the suspect, notify the health authorities and the secretary of the commission, and examine each member of the dairy force, and in every inflammatory affection of the nose or throat occurring among the employees of the dairy, in addition to carrying out the above-mentioned program, the attending physician shall take a culture and have it examined at once by a competent bacteriologist approved by the commission. Pending such examinat.on, the affected employee or employees shall be quarantined.

95. It shall be the duty of the secretary, on receiving notice of any suspicious or contagious disease at the dairy, at once to notify the committee having in charge the medical supervision of employees of the dairy farm upon which such disease has developed. On receipt of the notice this committee shall assume charge of the matter, and shall have power to act for the commission as its judgment dictates. As soon as possible thereafter, the committee shall notify the commission, through its secretary, that a special meeting may be called for ultimate consideration and action. 
96. When a case of contagious disease is found among the employees of a dairy producing certified milk under the control of a medical milk commission, such employee shall be at once quarantined and as soon as possible removed from the plant, and the premises fumigated.

When a case of contagion is found on a certified dairy it is advised that a printed notice of the facts shall be sent to every householder using the milk, giving in detail the precautions taken by the dairyman under the direction of the commission, and it is further advised that all milk produced at such dairy shall be heated at $145^{\circ} \mathrm{F}$. for 40 minutes, or $155^{\circ} \mathrm{F}$. for 30 minutes, or $167^{\circ} \mathrm{F}$. for 20 minutes, and immediately cooled to $50^{\circ} \mathrm{F}$. These facts should also be part of the notice, and such heating of the milk should be continued during the accepted period of incubation for such contagious disease.

The following method of fumigation is recommended:

After all windows and doors are closed and the cracks sealed by strips of paper applied with flour paste, and the various articles in the room so hung or placed as to be exposed on all sides, preparations should be made to generate formaldehyde gas by the use of 20 ounces of formaldehyde and 10 ounces of permanganate of potash for every 1,000 cubic feet of space to be disinfected.

For mixing the formaldehyde and potassium permanganate a large galvanized-iron pail or cylinder holding at least 20 quarts and having a flared top should be used for mixing therein 20 ounces of formaldehyde and 10 ounces of permanganate. A cylinder at least 5 feet high is suggested. The containers should be placed about in the rooms and the necessary quantity of permanganate weighed and placed in them. The formaldehyde solution for each pail should then be measured into a wide-mouthed cup and placed by the pail in which it is to be used.

Although the reaction takes place quickly, by making preparations as advised all of the pails can be "set off" promptly by one person, since there is nothing to do but pour the formaldehyde solution over the permanganate. The rooms should be kept closed for four hours. As there is a slight danger of fire, the reaction should be watched through a window or the pails placed on a noninflammable surface.

97. Following a weekly medical inspection of the employees, 8 monthly report shall be submitted to the secretary of the medical milk commission, on the same recurring date by the examining visiting physician.

The following schedule, filled out in writing and signed by himself, is recommended as a suitable form for the attending physician's report:

This is to certify that, on the dates below indicated, official visits were made to the dairy, owned and conducted by, 1 of - (indicating town and State), where careful inspections of the dairy employees were made.

(a) Number and dates of visits since last report. -

(b) Number of men employed on the plant.

(c) Has a recent epidemic of contagion occurred near the dairy, and what was its nature and extent?

(d) Have any cases of contagious or infectious disease occurred among the men since the last report?

(e) Disposition of such cases.

(f) What individual sickness has occurred among the men since the last report?

(g) Disposition of such cases.

(h) Number of employees now quarantined for sickness.

(i) Describe the personal hygiene of the men employed for milking when prepared for and during the process of milking.

(j) What facilities are provided for sickness in employees?

(k) General hygienic condition of the dormitories or houses of the employees.

(l) Suggestions for improvement.

$(m)$ What is the hygienic condition of the employees and their surroundings?

(n) How many employees were examined at each of the foregoing visits?

(o) Remarks.

Date, $\longrightarrow$.

Attending Physician. 


\section{LIBRARY OF CONGRESS}

|||||||||||||||||||||||||||||||||||||||||||

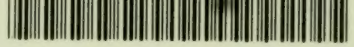

00008958142 